\title{
The Students' Ability In Writing Skill: Using Personal Pronoun In Narrative text
}

\author{
Rahmawati \\ rahmawati165@gmail.com \\ Universitas Prima Indonesia, Indonesia \\ Ernita Fariani Sinaga (Corresponding Author) \\ ernitafariani@gmail.com \\ Universitas Prima Indonesia, Indonesia \\ Anjelia Saragih \\ anjeliasaragih99@gmail.com \\ Universitas Prima Indonesia, Indonesia \\ Sukutenta Br Sembiring \\ sukutenta.sembiring@yahoo.com \\ Universitas Prima Indonesia, Indonesia
}

\begin{abstract}
This study aims to determine the EFL students' ability to use personal pronouns in narrative text. The subject of this study are students of second grade and the object of this study was the students' ability to use pronouns in narrative text. The sample of this study are 16 students. Data collection techniques in this study use test and interviews. Based on the data analyzed, the researchers concluded that the students' ability to use pronouns in the narrative text was $68.43 \%$ and the students' ability to use personal pronouns in the narrative text is $62.93 \%$. The study concludes that the difficulty affecting students in using pronouns was a lack of understanding of pronouns and narrative text even though they had been taught by the teacher and the lack of grammar books.
\end{abstract}

Keywords: Writing skills; narrative text; personal pronouns

\section{A. INTRODUCTION}

In writing, mastering grammar is essential. This is the basis of mastery of written language. Without mastering grammar, it is hard for the students in this context to build their writing product readable. Grammar is a description of a language's structure and how linguistic units such as words and phrases are combined to produce sentences in a language (Hodgson, 2020; Huddleston et al., 1988; Knapp \& Watkins, 2005; Riley, 
1997). It means that language ability, whether spoken or written, can be evaluated based on the grammar used. Even the use of grammar influence language meaning. According to Jones \& Quinn (2014), there are eight parts of speech in English grammar: noun, pronoun, verb, adverb, adjective, conjunction, preposition, and interjection.

There are four types of writing, namely descriptive, narrative, expository, and persuasive or argumentative (Almacioğlu \& Okan, 2018; Watcharapunyawong \& Usaha, 2013). Each text has its' social function, language features, paragraph structure (Abbaszadeh, 2013; Martin, 1992; Phichiensathien, 2018). Learning a text type in English can be separated with grammatical and one of the crucial things is English pronouns. We must pay attention to several writing ways, especially in the narrative text which tells about a fairytale story. The subject of the narrative text consists of narrating events, action or movement in the narrative. Sentences are usually arranged according to time order. According to Ferarri (2015) narrative paragraphs tell a series of related events: first this happened, then this happened, then this happened.

In this research, the researcher's discuss about pronoun mostly Personal Pronouns. Personal Pronouns has eight types: Personal pronouns (subject and object pronouns), possessive pronouns, reflexive pronouns, demonstrative pronouns, interrogative pronouns, relative pronouns, indefinite pronouns, and reciprocal pronouns. In this case, the researcher's take subject pronouns and complement pronouns (objects pronouns) in narrative text. Personal Pronoun is part of grammar. It is crucial in teaching and learning English. According to Carey (2015) and Mpiranya (2020) personal pronoun are indicated by three forms, i.e. do they refer to the speaker, who was spoken to, or is being discussed. In this research, Personal pronouns mean the words used in place of nouns, like as: I, you, we, they, him, her, his, it, etc. It is vital to know. If you ignore the personal pronouns in the text, you have to repeat the same person's name or nouns in a sentence, that's why we have to change their pronouns because we don't know what should we put in a sentence. According to Carey (2015) and Berry (2018) pronouns are words used instead of nouns when we don't want someone's name or something directly, for example, subjects and objects pronouns. 
According to (Mpiranya, 2020; Rounds, 1987; Stormbom, 2019; Uz, 2014) there are kinds of Personal Pronouns. They are personal pronouns agreement with noun, agreement with indefinite pronouns, agreement with collective nouns. As an English learner, the material about Pronouns should not be underestimated. The use of pronouns in a text has a crucial position in determining which sentences are legible and the meaning contained in them can be captured (Qi, 2010). Therefore, the researcher considers that research that studies English pronouns should also receive important attention for researchers.

Several previous studies examined English Pronouns such as (Anderson, 1998; Che Hassan et al., 2019; Kitagawa \& Lehrer, 1990; Qi, 2010; Uz, 2014). Those studies concern on how personal pronouns used in different context, while this present study discuss about the use of pronoun in academic writing in the form of narrative text. The subject of this study also focused on junior high school students, so it make a little different with previous research mentioned above.

According to the problems found by the researchers related to the use of English Pronouns, This study aims to explore further about the ability of EFL students in this case Junior high school students in using Pronouns in writing narrative text. Furthermore, the researcher also aims to determine the obstacles faced by students in the learning process, especially material related to English Pronouns.

\section{B. RESEARCH METHOD}

\section{Research Design}

This research used quantitave descriptive ti describe the score of students and qualitative approach to depply understanding the students' obstacles in learning or using English pronoun in writing. This seeting of the research took place in Junior High School of Talitakum Medan. The subject of the research was the students of SMP Talitakum. The object of the research was the students' ability by using personal pronouns in narrative text. The sample of this research was the students at second grade, amounting to 16 students. 


\section{Instruments for collecting the data}

There are two main instruments for collecting data in this study, those are test and interviewed guideline. Test aimed to collect data about students' ability to use personal pronouns in narrative text. The researcher's used five aspect's of writing to measure the ability of students' to use pronouns. Interview guideline was open-endeed question and record the answers. The researcher's then transcribe and types the data into a computer file for analysis. In this step, the researcher's conducted interview about the students' obstacels in using personal pronoun in narrative text.

Technique of data analysis

The data collected form test result were analyzed and interpreted by using qualitative scores to get summary (Creswell, 2014; Silverman, 2004) In this case, the researcher's use 5 categories: very good, good, enough, less and bad. Then the data from interviews were transcribed and interpreted using Huberman theory (Matthew B.M., A.M Huberman, Saldana, 2014).

The formula used to describe the data quantitatively as follows;

$P=\frac{F}{N} X 100 \%$

$\mathrm{P}=$ Percentage

$\mathrm{F}=$ number of frequency

$\mathrm{N}=$ number of respondents

In order to find out the categories of students ability by using personal pronouns in narrative, the researcher's presents class friction of the scores are as follow :

Very good (A) : : $\quad$ : $\quad 100$

Good (B) : : : $\quad$ : $\quad$ :

Enough $(\mathrm{C}) \quad: 60-69$

Less (D) : :50-59

$\operatorname{Bad}(\mathrm{E}) \quad: 0-49$ 
$\mathrm{Mx}=\frac{\sum x}{N}$

$\mathrm{Mx}=$ Mean or Average score

$\sum \mathrm{x}=$ The sum of score and frequency

$\mathrm{N}=$ Number of case

\section{FINDINGS AND DISCUSSION}

\section{Findings}

\section{Data presentation}

The research data was taken from the results of students' test scores on the use of pronouns in narrative texts. There were 16 students who were the subjects in this research. In data collection, the researcher's used writing tests as data instruments. The researcher's gave 2 narrative text story titles, namely mouse deer \& crocodile, and hunter \& woodcutter. And then the researcher's asked the students to choose one of the titles to make a narrative text as a result of research data.

The students ability in using personal pronoun in narrative text

Table I. The Students' Score in Using Subject Pronouns in Narrative Text

\begin{tabular}{cccc}
\hline No & Students & Scores & Category \\
\hline 1. & AS & 56 & Less \\
\hline 2. & AS & 67 & Enough \\
\hline 3. & BM & 75 & Good \\
\hline 4. & DG & 87 & Very good \\
\hline 5. & FO & 58 & Less \\
\hline 6. & GS & 60 & Enough \\
\hline 7. & HS & 60 & Enough \\
\hline 8. & JM & 62 & Enough \\
\hline 9. & JN & 89 & Very good \\
\hline 10. & KN & 85 & Very good \\
\hline 11. & LS & 75 & Good \\
\hline 12. & MT & 78 & Good \\
\hline 13. & PS & 74 & Good \\
\hline 14. & PP & 74 & Good \\
\hline 15. & PP & 30 & Bad \\
\hline 16. & RH & 65 & Enough \\
\hline
\end{tabular}


Rahmawati, Ernita Fariani Sinaga, Anjelia Saragih \& Sukutenta Br Sembiring

Table 2. Table Percentage Of Subject Pronoun

\begin{tabular}{cccc}
\hline No & Category & Frequency & Percentages \\
\hline 1. & Very good & $\mathbf{3}$ & $\mathbf{1 8 , 7 5}$ \\
\hline 2. & Good & $\mathbf{5}$ & $\mathbf{3 1 , 2 5}$ \\
\hline 3. & Enough & $\mathbf{5}$ & $\mathbf{3 1 , 2 5}$ \\
\hline 4. & Less & $\mathbf{2}$ & $\mathbf{1 2 , 5}$ \\
\hline 5. & Bad & $\mathbf{1}$ & $\mathbf{6 , 2 5}$ \\
\hline & Total & $\mathbf{1 6}$ & $\mathbf{1 0 0 \%}$ \\
\hline
\end{tabular}

Table 3. The Students' Score in Using Object Pronouns in Narrative Text

\begin{tabular}{cccc}
\hline No & Students & Scores & Category \\
\hline 1. & AS & 50 & Less \\
\hline 2. & AS & 60 & Enough \\
\hline 3. & BM & 70 & Good \\
\hline 4. & DG & 75 & Good \\
\hline 5. & FO & 50 & Less \\
\hline 6. & GS & 58 & Less \\
\hline 7. & HS & 60 & Enough \\
\hline 8. & JM & 55 & Less \\
\hline 9. & JN & 90 & Very good \\
\hline 10. & KN & 85 & Very good \\
\hline 11. & LS & 60 & Enough \\
\hline 12. & MT & 70 & Good \\
\hline 13. & PS & 60 & Enough \\
\hline 14. & PP & 75 & Good \\
\hline 15. & PP & 20 & Bad \\
\hline 16. & RH & 69 & Enough \\
\hline
\end{tabular}

Table 4. Table Percentage Of Object Pronoun

\begin{tabular}{cccc}
\hline No & Category & Frequency & Percentages \\
\hline 1. & Very good & 2 & 12,5 \\
\hline 2. & Good & 4 & 25 \\
\hline 3. & Enough & 5 & 31,25 \\
\hline 4. & Less & 4 & 25 \\
\hline 5. & Bad & 1 & 6,25 \\
\hline & Total & 16 & $100 \%$ \\
\hline
\end{tabular}


Tabel 5. The Students' Score Ability In Using Personal Pronoun In Narrative Text

\begin{tabular}{|c|c|c|c|c|c|c|}
\hline \multirow[t]{2}{*}{ No. } & \multirow[t]{2}{*}{ Students } & \multicolumn{2}{|c|}{$\begin{array}{c}\text { Kinds of personal } \\
\text { pronoun }\end{array}$} & \multirow[t]{2}{*}{ Amount } & \multirow[t]{2}{*}{ Average } & \multirow[t]{2}{*}{ Category } \\
\hline & & subject & object & & & \\
\hline 1. & $\mathrm{AS}$ & 56 & 50 & 106 & 53 & Less \\
\hline 2. & $\mathrm{AS}$ & 67 & 60 & 127 & 63,5 & Enough \\
\hline 3. & $\mathrm{BM}$ & 75 & 70 & 145 & 72,5 & Good \\
\hline 4. & DG & 87 & 75 & 162 & 81 & $\begin{array}{l}\text { Very } \\
\text { Good }\end{array}$ \\
\hline 5. & $\mathrm{FO}$ & 58 & 50 & 108 & 54 & Less \\
\hline 6. & GS & 60 & 58 & 118 & 59 & Less \\
\hline 7. & $\mathrm{HS}$ & 60 & 60 & 120 & 60 & Enough \\
\hline 8. & $\mathrm{JM}$ & 62 & 55 & 117 & 58,5 & Less \\
\hline 9. & $\mathrm{JN}$ & 89 & 90 & 179 & 89,5 & $\begin{array}{l}\text { Very } \\
\text { good }\end{array}$ \\
\hline 10. & $\mathrm{KN}$ & 85 & 85 & 170 & 85 & $\begin{array}{l}\text { Very } \\
\text { good }\end{array}$ \\
\hline 11. & $\mathrm{LS}$ & 75 & 60 & 135 & 67,5 & Enough \\
\hline 12. & MT & 78 & 70 & 148 & 74 & Good \\
\hline 13. & PS & 74 & 60 & 134 & 67 & Enough \\
\hline 14. & PP & 74 & 75 & 149 & 74,5 & Good \\
\hline 15. & $\mathrm{PP}$ & 30 & 20 & 50 & 25 & Bad \\
\hline 16. & RH & 65 & 69 & 134 & 67 & Enough \\
\hline
\end{tabular}

The difficulties of the students' ability in using personal pronouns in narrative text

After the students completed the test, the researcher's conducted interviews with 5 students about the students' abilities in using personal pronouns in narrative text at SMP Talitakum. Which aims to know the difficulties that affect students in using personal pronouns in narrative text. To get the results of the interview data, there researcher's asked the students several questions and recorded the results of the interview. The following is a conversation between students and researchers:

\section{Conversation 1}

Teacher : " Do you like studying English?"

Students 1 : "Yes, I do"

Teacher : "Do you know narrative text and personal pronouns?"

Students 1 : "Yes, I do"

Teacher : "What is the meaning of personal pronoun and narrative text?"

Student 1 : "A personal pronoun is a pronoun used for a specific person, animal, object or thing. This pronoun depends on the role (subject, object, 
possessive), number, person-th, and gender of the noun being replaced. Narrative text is a non-fiction story that can take the form of fairy tales, myths, folk tales, animal stories, and so on"

Techer : "What are personal pronouns based on your understanding?"

Student 1 : "Personal pronouns consist of subject and object. They are I, you, we, they, him, her, us, them, me."

Teacher : " Do you find any difficulties in studying personal pronouns?" what are they?"

Student $2 \quad$ : "Yes, I do. I can not differentiated between them."

Teacher : " Do you find any difficulties in arranging narrative paragraph?"

Student 2 : "Yes, I do"

Teacher : "What are your difficulties in arranging narrative paragraph?"

Student 2 : " I don't know and I can not arrange narrative."

Teacher : "Do you understand what your teacher taught about personal pronoun and narrative text?"

Student 2 : "Yes, I do"

Teacher : "Do you have grammar book?"

Student 2 : "Yes, I do"

\section{Conversation 2}

Teacher

Student 3

Teacher

Student 3

Teacher

Student 3

Teacher

Student 3

Teacher

Student 3

Teacher

Student 3

Teacher

Student 3

Teacher

Student 3

Teacher

Student 3
:" Do you like studying English?"

: "Yes"

: "Do you know narrative text and personal pronouns?"

: "Yes"

: "What is the meaning of personal pronoun and narrative text?"

$:-$

: "What are personal pronouns based on your understanding?"

: "Personal pronoun is subject and object"

: "Do you find any difficulties in studying personal pronouns?" what are they?"

: "No"

: "Do you find any difficulties in arranging narrative paragraph?"

: "Yes"

: "What are your difficulties in arranging narrative paragraph?"

: "The meaning about narrative"

: "Do you understand what your teacher taught about personal pronoun and narrative text?"

: "Yes"

: "Do you have grammar book?"

: "No"

Based on the above conversation, the researcher's concluded that it is difficult what affects students in using personal pronouns is in learning personal pronouns because there are no grammar books for students and they don't understand what 
personal pronoun and narrative text are even though they have been explained by the field teacher.

\section{Data analysis}

\section{The students' ability in using personal pronouns in narrative text}

Data analysis was done by formula :

$$
P=\frac{F}{N} X 100
$$

a) The students who scores in the very good category are in number $4,9,10$.

$$
P=\frac{3}{16} X 100 \%=18,75
$$

b) The students who scores in the good category are in number $3,12,14$

$$
P=\frac{3}{16} X 100 \%=18,75
$$

c) The students who scores in the enough category are in number $2,7,11,13,16$

$$
P=\quad P=\frac{5}{16} X 100 \%=31,25
$$

d) The students who scores in the less category are in number $1,5,6,8$

$$
P=\frac{4}{16} X 100 \%=25
$$

e) The students who score in the bad category is in number 15

$$
P=\frac{1}{16} X 100 \%=6,25
$$

After the data were analyzed, the authors concluded that the percentage of students' ability to use pronouns in narrative paragraphs is:

Table 6. The Percentage of Students' Ability

\begin{tabular}{rcccc}
\hline No. & Category & Score & Frequency & Percentage \\
\hline 1. & Very good & $80-100$ & 3 & $18,75 \%$ \\
\hline 2. & Good & $70-79$ & 3 & $18,75 \%$ \\
\hline 3. & Enough & $60-69$ & 5 & $31,25 \%$ \\
\hline 4. & Less & $50-59$ & 4 & $25 \%$ \\
\hline 5. & Bad & $0-49$ & 1 & $6,25 \%$ \\
\hline & Total & & 16 & $100 \%$ \\
\hline
\end{tabular}

Based on the table above, there are 16 students who took the writing test, 3 students $(18.75 \%)$ were in the very good category, 5 students $(31.25 \%)$ were in the good category, $3(18.75 \%)$ students were in the enough category, $4(25 \%)$ students were in the less category, and 1 student (6.25\%) was in the bad category. It can be concluded that the level ability of the second year in SMP TALITAKUM is in the middle category. This finding can be ilusrated as the diagram bellow: 


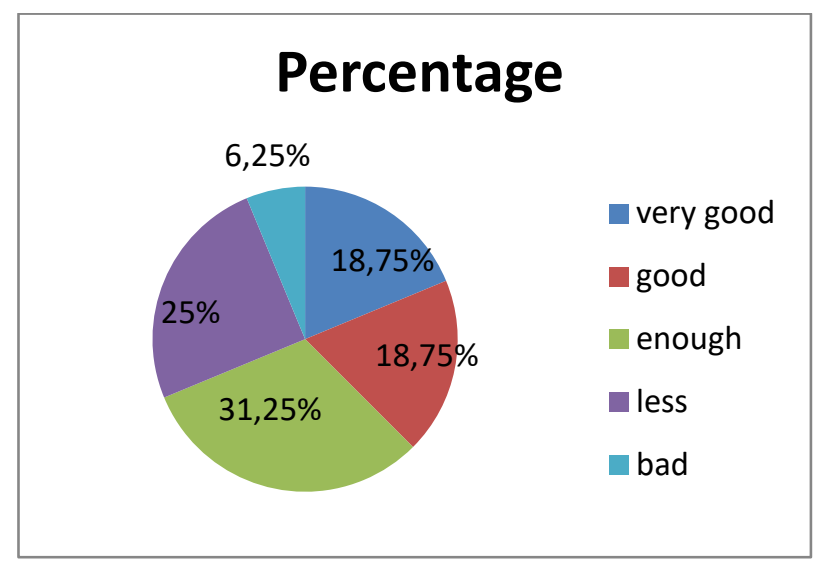

A. The student's ability in using subject pronouns in narrative is 68,43

B. The student's ability in using object pronouns in narrative is 62,93

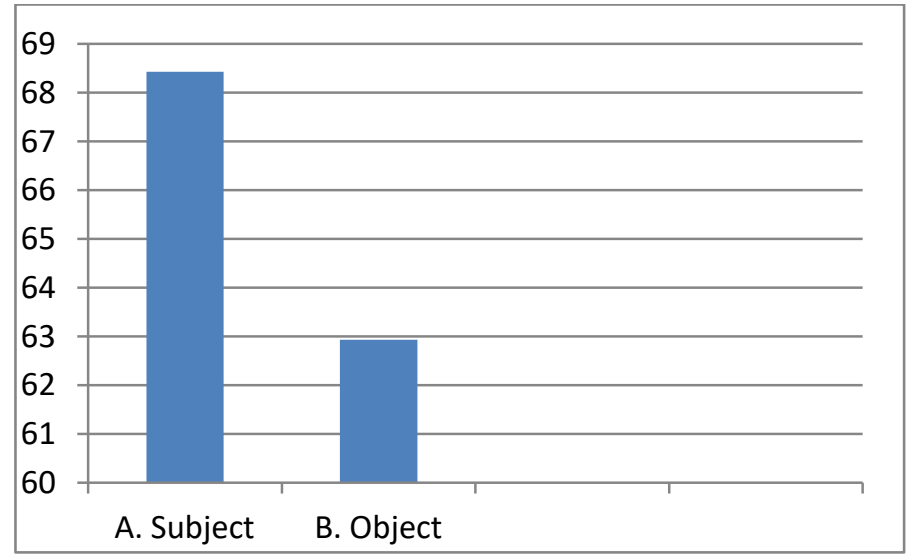

The difficulties of the students' ability in using personal pronouns in narrative text

Based on the results of the dialogue above, after the researcher conducted interviews with several second grade students, the researcher concluded that the difficulty affecting the students' ability to use pronouns was the lack of understanding of personal pronouns and understanding of narrative text even though it had been taught by the subject teacher and the lack of books was one of the obstacles students in understanding personal pronouns and narrative texts.

\section{Discussion}

During the research, the researchers found that the students' ability in understanding personal pronouns, namely using and knowing I, you, we, they, him, her and it were in the enough category. In accordance with what was found by Mellie and Paniene (1976 in Nurislami, 2004: 7) the pronoun person is displayed in 3 forms, 
namely whether it refers to the speaker, who is being talked to, or who is being discussed. In this study, personal pronouns mean words that are used to replace nouns, such as: I, you, we, they, him, her, his, it, etc. Because this is very important to know. If you don't pay attention to the personal pronoun in the text, then you have to repeat the same person's name or noun in a sentence, therefore we have to replace the person's pronoun because we don't know what to put in the sentence.

In this study, a personal pronoun is associated with narrative text. The researchers found that the students' ability in making narrative text was still in the less category. This is due to the students' lack of understanding about narrative text according to Glatthorn's (1980 in Nurhidayati, 2006: 3) narrative paragraphs telling a series of related events: first this happened, then this happened, then this happened.

The researchers found that the ability to read narrative text of the second grade students of SMP Talitakum Medan in reading narrative text was in the enough category. In collecting data, researchers used two techniques, namely tests and interviews. After collecting data, the researcher found that the students' ability to use pronouns in narrative text was in the enough category because the students' ability to use pronouns in the subjects in the text was $68.43 \%$ and the students' ability to use noun pronouns in the narrative text is $62.93 \%$.

\section{CONCLUSION}

Based on the research above, it can concluded that the students' ability to use pronouns in narrative text is in enough category, because from the overall test results students don't understand pronouns in narrative text. The results showed that the students 'ability to use pronouns in narrative text subject matter was categorized as "enough" with a score of $68.43 \%$, and the students' ability to use object pronouns in narrative text was categorized as "sufficient" with a score of $62.93 \%$.

From these results, that the students' ability to understand pronouns is sufficient. This is due to the difficulties experienced by students, namely the lack of understanding of personal pronouns in narrative texts even though they have been taught by the teacher, and also the lack of grammar books that students have.

Based on the research results, the researcher wants to provide some suggestions to put forward. They are as follows: Students must be more active in the classroom during 
the learning time, teachers must pay more attention to students, in order to recognize and improve students' abilities, students are advised to practice alone at home to improve their respective abilities, teachers often provide exercises and assignments to students about pronouns in narrative texts, students are required to have and study books. English books, especially grammar books and notebooks, and for future researchers, this research can be used as a reference for researchers who are interested in conducting further research related to personal pronouns in text narrative.

\section{REFERENCES}

Abbaszadeh, Z. (2013). Genre-Based Approach and Second Language Syllabus Design. Procedia - Social and Behavioral Sciences, 84, 1879-1884. https://doi.org/10.1016/j.sbspro.2013.07.052

Almacioğlu, G., \& Okan, Z. (2018). Genre-based approach to writing instruction for students at an english language and literature department. Eurasian Journal of Applied Linguistics, 4(1), 71-100. https://doi.org/10.32601/ejal.460635

Anderson, R. T. (1998). The development of grammatical case distinctions in the use of personal pronouns by Spanish-speaking preschoolers. Journal of Speech, Language, and Hearing Research. https://doi.org/10.1044/jslhr.4102.394

Berry, R. (2018). Personal pronouns. In From Words to Grammar. https://doi.org/10.4324/9781315712567-3

Carey, A. L., Brucks, M. S., Küfner, A. C. P., Holtzman, N. S., Deters, F. G., Back, M. D., Brent Donnellan, M., Pennebaker, J. W., \& Mehl, M. R. (2015). Narcissism and the use of personal pronouns revisited. Journal of Personality and Social Psychology. https://doi.org/10.1037/pspp0000029

Che Hassan, N. S. I., Mohammad N, N. H., Rosly, R., \& Wan Z., W. N. F. (2019). ESL Learners' Language Errors in a Reflective Writing Assessment. Issues in Language Studies, 8(1), 37-51. https://doi.org/10.33736/ils.1291.2019

Creswell, J. W. (2014). Research Design:Qualitative, Quatitative and Mixed Method Approaches. Fourth Edition. In Singapore University of Nebraska-Lincoln.

Ferrari, R. (2015). Writing narrative style literature reviews. Medical Writing. https://doi.org/10.1179/2047480615z.000000000329

Hodgson, J. (2020). How to teach grammar. English in Education. https://doi.org/10.1080/04250494.2020.1780827

Huddleston, R., Quirk, R., Greenbaum, S., Leech, G., \& Svartvik, J. (1988). A Comprehensive Grammar of the English Language. Language. https://doi.org/10.2307/415437

Jones, D. S., \& Quinn, S. (2014). An Introduction to Functional Grammar (Issue December).

https://www.functionalmedicine.org/files/library/Intro_Functional_Medicine.pdf

Kitagawa, C., \& Lehrer, A. (1990). Impersonal uses of personal pronouns. Journal of Pragmatics. https://doi.org/10.1016/0378-2166(90)90004-W

Knapp, P., \& Watkins, M. (2005). Genre, text, grammar: Technologies for teaching and 
assessing writing. Education.

Martin, J. R. (1992). English Text: System and Structure. In A Study of Concepts.

Matthew B.M., A.M Huberman, Saldana, J. (2014). Qualitative Data Analysis. Sage Publication,Inc.

Mpiranya, F. (2020). Personal pronouns. In Swahili Grammar and Workbook. https://doi.org/10.4324/9781315750699-11

Phichiensathien, P. (2018). Genre-based approach in Academic English Writing. October.

Qi, R. (2010). Pronoun acquisition in a Mandarin-English bilingual child. International Journal of Bilingualism. https://doi.org/10.1177/1367006909356649

Riley, K. (1997). A Communicative Grammar of English. In Journal of English Linguistics. https://doi.org/10.1177/007542429702500211

Rounds, P. L. (1987). Multifunctional personal pronoun use in an educational setting. English for Specific Purposes. https://doi.org/10.1016/0889-4906(87)90072-X

Silverman, D. (2004). Qualitative Research: Theory, Method and Practice. In Qualitative Research.

Stormbom, C. (2019). Language change in L2 academic writing: The case of epicene pronouns. Journal of English for Academic Purposes. https://doi.org/10.1016/j.jeap.2019.02.001

Uz, I. (2014). Individualism and First Person Pronoun Use in Written Texts Across Languages. Journal of Cross-Cultural Psychology. https://doi.org/10.1177/0022022114550481

Watcharapunyawong, S., \& Usaha, S. (2013). Thai EFL students' writing errors in different text types: The interference of the first language. English Language Teaching. https://doi.org/10.5539/elt.v6n1p67 